\title{
A System to \\ Measure \\ Evapotranspiration \\ of In-ground \\ Container Plants \\ of Mexican Elder
}

\author{
Rolston St. Hilaire, ${ }^{1}$ \\ Cathleen F. Feser, ${ }^{2}$ \\ Theodore W. Sammis ${ }^{3}$, and \\ Anderson S. St. Hilaire ${ }^{4}$
}

Additional indeX words. crop coefficient, landscape trees, nursery production, pot-in-pot, Sambucus mexicana

Summary. Accurate measurement of evapotranspiration (ET) is difficult and expensive for large, in-ground container (pot-in-pot) plants. We engineered and used a simple and inexpensive system to determine evapotranspiration of in-ground container trees. The system was shopassembled and used a block and tackle system attached to a collapsible tripod. A unique container harness system attached to the block and tackle system was used to lift containers that were sunken in the ground. Containers were weighed with a battery-operated balance that was accurate to $1 \mathrm{~g}(0.04 \mathrm{oz})$ at its maximum load capacity of $60 \mathrm{~kg}$ $(132.3 \mathrm{lb})$. One person operated the system, and the weight of the system exclusive of the balance was $17.5 \mathrm{~kg}$ $(38.50 \mathrm{lb})$. Gravimetric water use data obtained with the system were

Contribution of the New Mexico Agricultural Experiment Station, New Mexico State University, Las Cruces. Mention of a trademark, proprietary product, or vendor does not constitute a guarantee or warranty of the product by New Mexico State University.

${ }^{1}$ Assistant professor and corresponding author, Department of Agronomy and Horticulture, New Mexico State University, Las Cruces, NM 88003; e-mail rsthilai@nmsu.edu.

${ }^{2}$ Graduate student, Department of Agronomy and Horticulture, New Mexico State University, Las Cruces, NM 88003.

${ }^{3}$ New Mexico State climatologist and professor; Department of Agronomy and Horticulture, New Mexico State University, Las Cruces, NM 88003.

${ }^{4}$ Undergraduate Crimson Scholar, Department of Mechanical Engineering, New Mexico State University, Las Cruces, NM 88003. 
combined with meteorological data to compute crop coefficients $\left(\mathrm{K}_{c}\right)$ of mexican elder (Sambucus mexicana). The system detected small changes in daily water use of mexican elder trees grown in $76-\mathrm{L}(20$-gal) in-ground containers. Crop coefficients ranged from 0.17 to 0.71 . The acquisition of evapotranspiration data from relatively large, containerized landscape plants may be facilitated because the system is simple, inexpensive, and accurate.

$\mathrm{P}$ lant production practices affect water use of container-grown plants (Regan, 1991). Typically, the nursery industry uses the conventional above ground container system for plant production (Young and Bachman, 1996). However, the in-ground container or pot-inpot (PIP) nursery production system improves biomass production (Ruter, 1998), reduces root zone temperature stress (Young and Bachman, 1996), and enhances efficient water use by decreasing container evapotranspiration (ET) (Martin et al., 1999). Also, labor costs are reduced (Adrian et al., 1998).

Contemporary experiments have utilized the in-ground container system to determine ET of relatively small plants (Martin et al., 1999). Evapotranspiration is the combination of evaporation from soil and transpiration from plants (Allen et al., 1994). However, Schuch and Burger (1997) cautioned that water consumption values determined for small plants are not applicable to large plants.

Evapotranspiration of large plants usually is determined with weighing lysimeters or predicted from ET models. Evapotranspiration data obtained with weighing lysimeters are scarce because these instruments are expensive and require skilled personnel for design and installation (Yrissarry and Naveso, 2000). A full-grown douglas fir (Pseudotsuga menziesii) was installed in a weighing lysimeter, but the lysimeter operated for only a few years because of operation and maintenance problems (Fritschen et al., 1977). Lysimeters [57L (15-gal) containers] were used to measure ET of argentine mesquite (Prosopisalba) ‘Colorado' and southern live oak (Quercus virginiana) 'Heritage' trees that were installed in containers at ground level (Levitt et al., 1995). The containers were lifted from the ground and ET was determined by weighing with an electronic precision balance. However, these lysimeters were small enough to be manually lifted by one person. Argentine mesquite, desert willow (Chilopsis linearis var. linearis) and southern live oak were grown in non draining lysimeters [190-L (50gal) containers] that were placed in open-ended concrete pipes located in the ground (Devitt et al., 1995). To weigh these trees, an electric hoist was mounted on a large rectangular metal frame and was positioned over each lysimeter. Although these systems obtain reliable ET data, they are not widely used because of their high cost, operational complexity, and maintenance problems. In addition, lysimeters that can be lifted by one person only provide ET data for small plants. Thus, a simple, inexpensive, and accurate gravimetric method is needed to determine the ET of large plants.

The accuracy of ET models is validated with studies that compare ET values predicted by the models with data obtained gravimetrically. Also, gravimetric water use values and meteorological data are used to calculate crop coefficients $\left(\mathrm{K}_{\mathrm{c}}\right)$ of non stressed crops (Doorenbos and Pruit, 1977) and ornamentals (Levitt et al., 1995). The crop coefficient has no units and it is computed by dividing crop evapotranspiration $\left(\mathrm{ET}_{\text {crop }}\right)$ by reference $\mathrm{ET}\left(\mathrm{ET}_{\mathrm{o}}\right)$ (Allen et al., 1998; Doorenbos and Pruit, 1977). Reference crop evapo- transpiration is ET from a reference surface, not short of water. The reference surface is a hypothetical $12-\mathrm{cm}$-tall (4.7-inch) reference crop with a fixed surface resistance of $70 \mathrm{~s} \cdot \mathrm{m}^{-1}$ and an albedo (reflectance) of 0.23 (Allen et al., 1998). Thus, the reference surface resembles a well-watered green grass surface that is uniform, actively growing and completely shading the ground. For container-grown trees, $\mathrm{ET}_{\text {crop }}$ is the depth of water loss and is calculated by dividing crop (tree) water loss in cubic centimeters by the total leaf area (TLA) in square centimeters (Levitt et al., 1995). Within a 24-h period, one method to assess tree water loss (in cubic centimeters) is to weigh the trees and convert the mass of water lost in grams to cubic centimeters. One gram of water has a volume of one cubic centimeter.

Calculations of water use normalized by TLA reduce scatter of $\mathrm{K}$ data more than the use of projected canopy area (Levitt et al., 1995). Additionally, the ratio of water use per TLA would be more relevant to an urban landscape setting because TLA is usually wellcorrelated with air temperature and carbon dioxide reduction as well as rainfall and dust interception (McPherson, 1991).

The objectives of this paper were to 1) describe a simple system we engineered to obtain gravimetric wa-

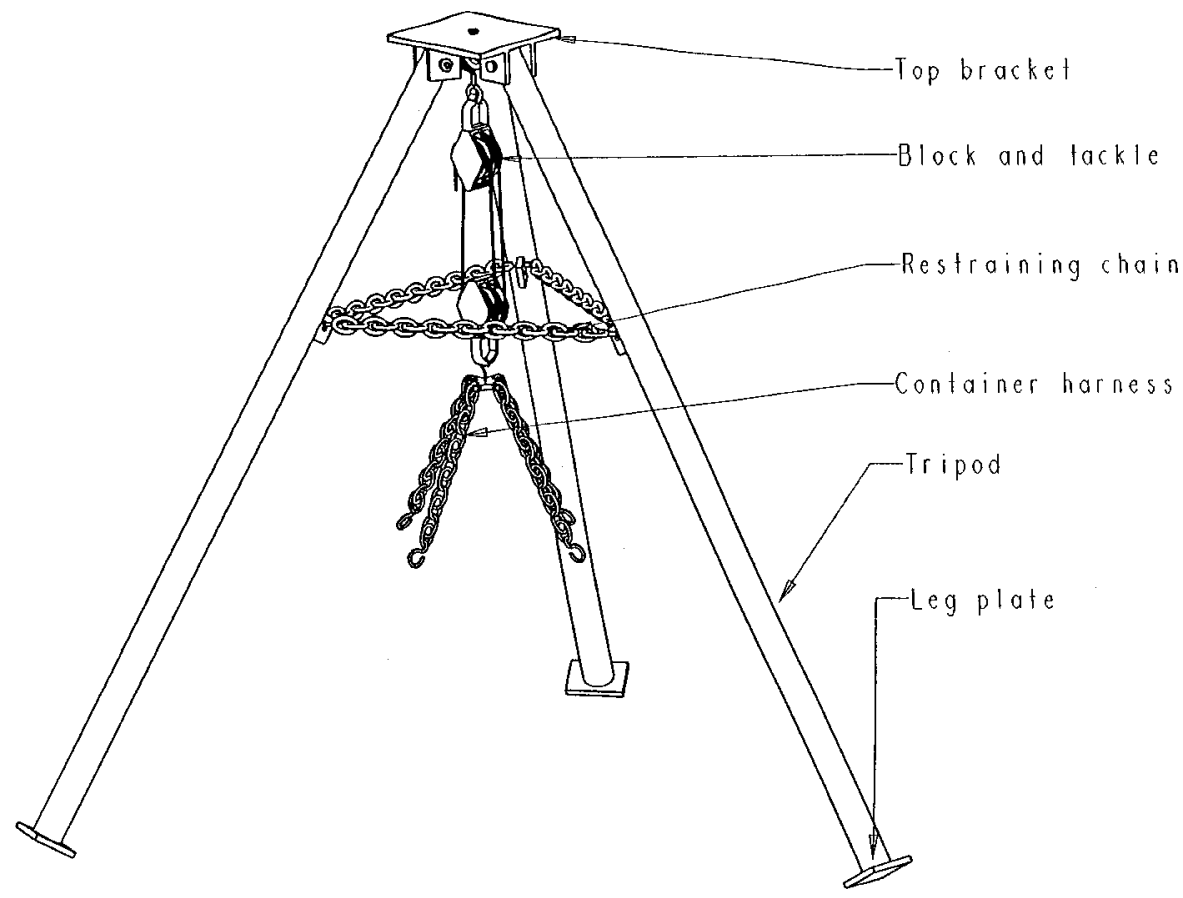

Fig. 1. Schematic of tripod, block and tackle, and container harness system used to lift in-ground container pots. 

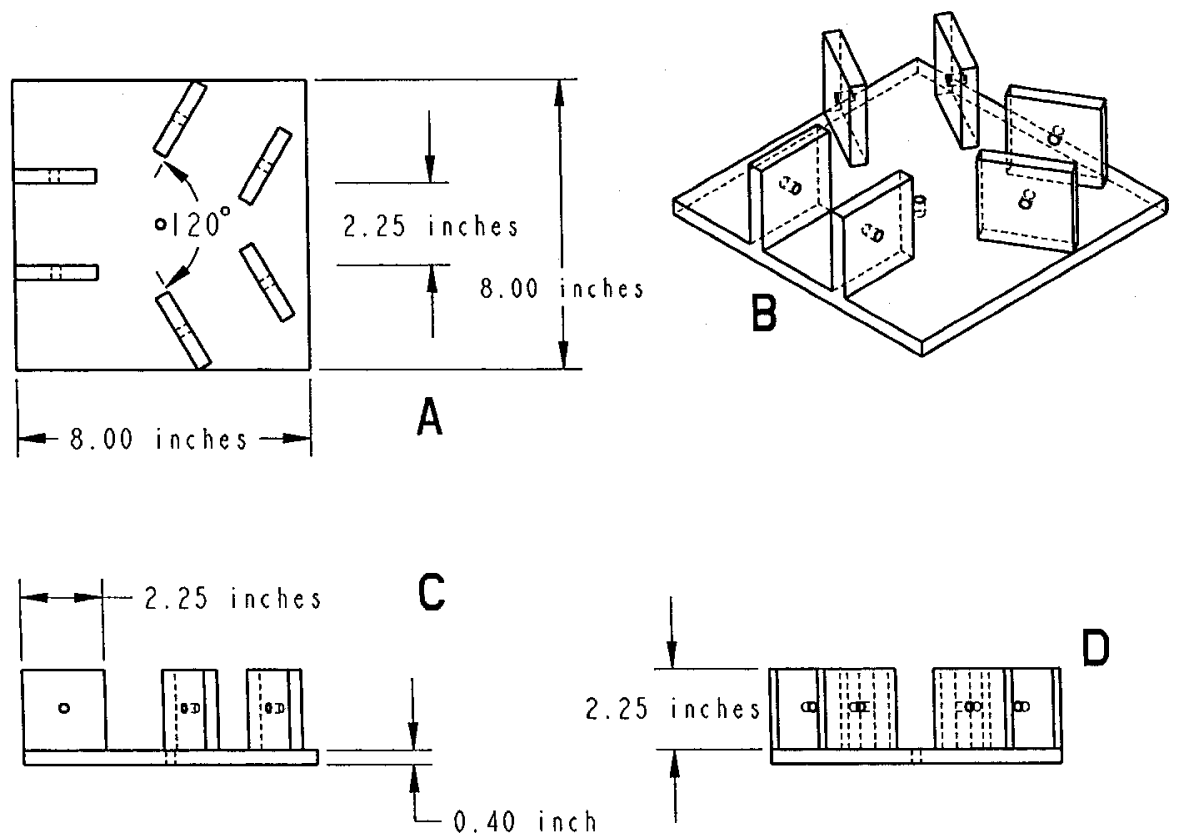

Fig. 2. Schematic of top bracket; $1.0 \mathrm{inch}=2.54 \mathrm{~cm}$. (A) Top view. (B) Orthogonal view. (C) Right hand view. (D) Front view.

ter use data due to evapotranspiration of large, in-ground container-grown mexican elder trees growing in an arid environment and 2 ) use the gravimetric water use data obtained with the system and meteorological data to calculate $\mathrm{K}_{\mathrm{c}}$ values of container-grown mexican elder.

\section{Materials and methods}

The system consists of a tripod, a block and tackle assembly, a container harness system, and data acquisition systems. These components, except the data acquisition systems, are illustrated schematically in Fig. 1.

TrIPOD SYSTEM. The tripod is composed of a top bracket that attaches to three cylindrical legs (Fig. 1). The top bracket and legs are made of $1.02-\mathrm{cm}$-thick (0.4-inch) aluminum. The top bracket consists of a $20.3 \times$ $20.3-\mathrm{cm}(8$-inch $)$ plate with a $1.27-\mathrm{cm}$ (0.5-inch) hole drilled through the center (Fig. 2A and B). A 2.5-cm (1inch) zinc-plated eye bolt is inserted through the hole and welded in place. Three pairs of $1.02-\mathrm{cm}$-thick aluminum plates are attached vertically to the top bracket (Fig. 1).

Each of the three pairs of plates is $5.461 \mathrm{~cm}$ wide $\times 5.715 \mathrm{~cm}$ long $(2.15$ $\times 2.25$ inches) and has a $1.27-\mathrm{cm}$ diameter hole in its center. Plates are welded to the top of the bracket (Fig. $2 \mathrm{C}$ and $\mathrm{D})$. A pair of plates is oriented at $120^{\circ}$ from an adjacent pair of plates (Fig. 2A and C).

Hortlechnology • January-March 2003 13(1) bolt on the top bracket. The bottom double pulley is inverted (hook side down) and the nylon rope is tied to its bottom end. The rope is threaded through the sheave rollers leaving enough excess length for comfortable hoisting. A large knot is tied in the rope at the front of the top pulley to prevent it from slipping back through the sheave roller.

Container harness system. Each of the ends of four equal lengths $(52.07 \mathrm{~cm})$ of twin-loop zinc chain (part no. 7012050; peerless Chain Co. Winona, Minn.) is attached to a 0.559 $\mathrm{cm}(0.22$-inch) zinc safety snap (National Mfg. Co.) (an aluminum plate with an eyebolt is shown in Fig. I because of software design limitations). The zinc safety snap is attached to the inverted hook on the bottom pulley. One 5.1-cm S-hook (National Mfg. Co.) is attached to each of the loose ends of each of the lengths of the twin loop chain. Each S-hook is hooked through one of four holes previously drilled on the perimeter of the container pot. Each hole is $1.27 \mathrm{~cm}$ in diameter and is drilled just below the lip of the container pot.

Data acquisition. To determine $\mathrm{ET}_{\text {crop }}$, in-ground containers with potted trees were lifted from the ground and weighed with a top-loading balance (model QC 60FEG-SOUR; Sartorius Corp., Edgewood, N.Y.). This balance is accurate to $\mathrm{lg}$ at its maximum load capacity of $60 \mathrm{~kg}$ and operates on either $110 \mathrm{~V}$ or a $30-\mathrm{V}$ rechargeable battery. The Horticultural Experiment Station weather station is located on a turfgrass surface 10 $\mathrm{m}(32.8 \mathrm{ft})$ east of the field where the in-ground containers were located. This station was equipped with a datalogger (CRI0X; Campbell Scientific, Logan, Utah) and recorded climate data using the following instrumentation: solar radiation (LI200S pyranometer; LI-COR, Lincoln, Neb.), precipitation (model TE525 tipping bucket raingage; Campbell Scientific), wind speed (model 024A wind speed sensor; Met One Instruments, Grants Pass, Ore.), and air temperature and relative humidity (model CS500 probe; Campbell Scientific). Data recorded by this weather station is accessible via the internet at New Mexico Climate Center (New Mexico Climate Center, 2002). $\mathrm{ET}_{0}$ was calculated from the meteorological data obtained from this weather station by town, Pa.) (Fig. 1). The top double pulley is hung by its hook to the eye 
using the grass-based, Penman's equation (Sammis et al., 1985).

Operation. We used the system to determine 24 -h water use of inground plants of mexican elder. The in-ground container system consisted of five mexican elder plants $(2.5-\mathrm{cm}$ caliper) potted on 13 Apr. 2001 into 76-L (20-gal) plastic container pots (top inside diameter $=48.3 \mathrm{~cm}$; height $=43.2 \mathrm{~cm}$; Classic 8000 Econo-Grip; Nursery Supplies, Orange, Calif.) placed into 76-L plastic socket pots (Classic 8000 Grip-Lip; Nursery Supplies) that were inserted into holes in the ground. Trees were potted in a mixture (by volume) 4 pine bark mulch (Hyponex Corp., Marysville, Ohio) : 1 washed sand (Certified Sand, Las Cruces, N.M.). To facilitate drainage, the bottom of each hole in the ground was lined with a $15.2-\mathrm{cm}$ (6-inch) thick gravel bed of $1.905 \mathrm{~cm}(0.75$ inch) screened rock (Certified Sand) before the socket pot was inserted into the ground. Pots were placed on the gravel bed at the bottom of the hole so that the 7.6-cm (3-inch) lip was above grade. Pots were in an open site at the Fabian Garcia Science Center [lat. $32^{\circ} 16^{\prime} 48^{\prime \prime} \mathrm{N}$, long. $106^{\circ} 45^{\prime} 18^{\prime \prime} \mathrm{N}$; elevation $1183 \mathrm{~m}(3903.9 \mathrm{ft})]$ at New Mexico State University and were spaced $2.59 \mathrm{~m}(8.5 \mathrm{ft})$ within rows and

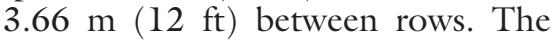
ground surface within and between rows was bare soil. During the period that 24 -h water use (18 Feb. to 20 Mar. 2002) was assessed, trees had an average height of $88 \pm 25 \mathrm{~cm}(35 \pm 10$ inches) and an average canopy width of $76 \pm 33 \mathrm{~cm}(30 \pm 13$ inches $)$. Total leaf surface (TLA) averaged $0.22 \mathrm{~m}^{2}$ $\left(2.368 \mathrm{ft}^{2}\right)$ per tree. Surface area of leaves was measured with a leaf area meter (LI 3000A; LI-COR) from three additional plants that were destructively harvested on the first day of the experiment. During the $30 \mathrm{~d}$ of the experiment there were no significant changes in leaf surface area, so the TLA from the initial harvest was used to normalize water use data.

The experimental unit was one tree. The five trees were watered every other day after 24 -h water use was assessed. On day one, pots were irrigated to saturation at $0600 \mathrm{HR}$ by an automatic irrigation system, allowed to drain for two hours, and an initial weight was recorded at $0800 \mathrm{HR}$. The irrigation system was switched off after initial weights were taken. To record weight, the tripod was placed over the in-ground container system and the container pot was hooked in four locations with the container harness system. The container pot was lifted by pulling down on the cord of the block and tackle. The pot was placed flat on a four-wheel hand truck and transported to the balance centrally located in the plot. On day two, trees were reweighed at $0800 \mathrm{HR}$ (after $24 \mathrm{~h}$ ) to determine 24-h water use and not irrigated until $0600 \mathrm{HR}$ on the morning of day three when the schedule of irrigation and weighing was repeated. Data was collected daily from $18 \mathrm{Feb}$. to 20 Mar. 2002 (30 d). There was no recorded precipitation during this period. The linear relationship of water use with time was analyzed by using General Linear Model procedures (GLM) of the Statistical Analysis System program package (SAS Inst., Cary, N.C.). The crop coefficient (K) of mexican elder was computed using the equation: $\left(\mathrm{K}_{\mathrm{c}}\right)=\mathrm{ET}_{\text {crop }} / \mathrm{ET}_{\mathrm{o}}$.

\section{Results and discussion}

Cost of materials and labor needed to assemble the tripod, block and tackle, and container harness system was $\$ 230.00$. These components weighed only $17.5 \mathrm{~kg}$ and provided a mechanical advantage of four. A mechanical advantage of four allows an operator to potentially deliver a lifting force that is four times the force applied. This relatively light weight and high mechanical advantage allowed one individual to record pot weights of up to $49.27 \mathrm{~kg}$ (108.620 lb). Maximum load capacity of the system is estimated at $272.2 \mathrm{~kg}(600 \mathrm{lb})$. The upper limit of tree height is about $6.0 \mathrm{ft}(1.83 \mathrm{~m})$, but the trunks of taller trees could be inclined to one side so that the top of the tree clears the top of the tripod.

During operation, two practices must be followed to ensure that the system functions smoothly. First, during breezy conditions, the balance must be shielded from wind to obtain a steady digital readout. The second practice that must be followed is that operators must ensure that the pots being weighed are not returned to socket pots so that the grooves on the rims of each of the two pots coincide. If the grooves on the pot coincide, then the pots lock into each other making it difficult to lift the holder pot for subsequent weighing.

$\mathrm{ET}_{\mathrm{o}}$ increased as the experiment progressed (Fig. 3A). During the 30$\mathrm{d}$ period, the system detected small changes in $24 \mathrm{~h}$ water use (Fig. 3B). Water use is a function of evaporation and transpiration and varies daily (Schuch and Burger, 1997). During the experimental period, $\mathrm{K}_{c}$ values were relatively unstable and ranged from 0.17 to 0.71 (Fig. 3C). We are not aware of any previously reported $\mathrm{K}_{c}$ values for mexican elder. Although plant developmental stage, growth rate, and changes in the leaf area index are expected to influence $\mathrm{K}$ for containerized woody plants (Regan, 1991), variations in $\mathrm{K}$ values could be attrib-
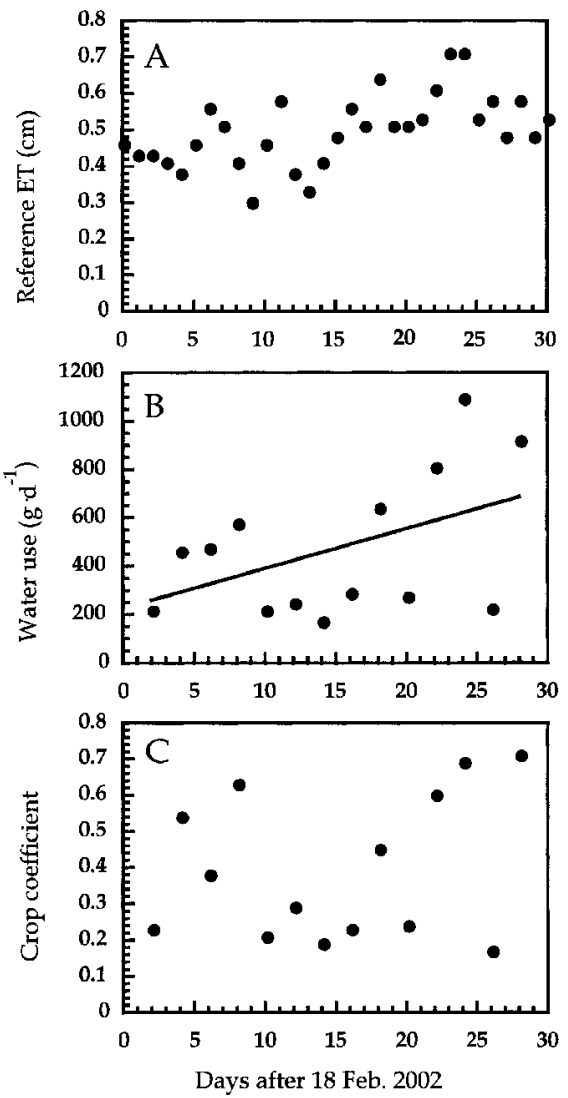

Fig. 3. (A) Reference evapotranspiration $\left(E T_{o}\right)$ at the experimental site as calculated from Penman's equation using meteorological data. Meteorological data used to calculate ET was obtained from a weather station that was adjacent to the experimental site. (B) Daily water use of in-ground container grown trees of mexican elder. Each point is the mean of five observations. Equation of regression line: $\mathrm{y}=225.8+17.1 \mathrm{x} ; r^{2}=0.15 .454$ $\mathrm{g}=1.0 \mathrm{lb}$. (C) Crop coefficient $\left(\mathrm{K}_{\mathrm{c}}\right)$ determined with daily water use data and reference evapotranspiration for in-ground container-grown mexican elder plants that were watered every other day. Each point is the mean of five values. 
uted to fluctuations in $\mathrm{E}_{\mathrm{o}}$. For example, wind speed is part of the empirically derived aerodynamic term that Penman's equation uses to calculate ET (Sammis et al., 1985). Thus, the fluctuations in wind speed that we recorded could influence ET. However, another possible explanation for the variation in $\mathrm{K}_{c}$ values is that there may be a difference between plant water use of species and the reference crop in response to changes in environmental conditions (Schuch and Burger, 1997). Our system could be used in future experiments to study how wind speed and other environmental factors impact water use of inground grown trees.

We conclude this relatively simple, portable and inexpensive system could be used to accurately determine evapotranspiration of large trees in an inground nursery production system. The system might be advantageous for lifting large pots that are sunken in the ground because these pots are typically difficult to lift by one person or by conventional nursery equipment such as a fork lift. Nursery managers could use the data on evapotranspiration to improve irrigation scheduling by applying water based on plant water loss. Also, scientists could gain a better understanding of how the in-ground container system influences water loss of large landscape plants.

\section{Literature cited}

Adrian, J.L., C.C. Montgomery, B.K. Behe, P.A. Duffy, and K.M. Tilt. 1998. Cost comparisons for infield, above ground container and pot-in-pot production systems. J. Environ. Hort. 16:65-68.

Allen, R.G., L.S. Pereira, D. Raes, and M. Smith. 1998. Crop evapotranspirationGuidelines for computing crop water requirements. FAO Irr. Drainage Paper 56, FAO, Rome.

Devitt, D.A., R.L. Morris, and D.S. Neuman. 1995. Evapotranspiration and growth response of three woody ornamental species placed under varying irrigation regimes. J.Amer. Soc. Hort. Sci. 1 19:452457.
Doorenbos, J. and W.O. Pruitt. 1977. Guidelines for predicting crop water requirements. FAO Irr. Drainage Paper 24. $2^{\text {nd }}$ ed. FAO, Rome.

Fritschen, L.J., J. Hsia, and P. Doraiswamy. 1977. Evapotranspiration of a douglas fir determined with a weighing lysimeter. Water Resources Res. 13:145-148.

Levitt, D.G., J.R. Simpson, and J.L. Tipton. 1995. Water use of two landscape tree species in Tucson, Arizona. J. Amer. Soc Hort. Sci. 120:409-416.

Martin, C.A., L.B. McDowell, and S. Bhattacharya. 1999. Below ground potin-pot effects on growth of two southwest landscape trees was related to root membrane thermostability. J. Environ. Hort. 17:63-68.

McPherson, E.G. 1991. Economic modeling for large-scale urban tree plantings, p. 349-369. In: E. Vine, D. Crawley, and P. Centolella (eds.). Energy efficiency and the environment: Forging the link. Amer. Council Energy-efficient Econ., Wash., D.C.

New Mexico Climate Center. 2002. NMSU monitored weather stations. 23 Mar. 2002. <http://www.weather.nmsu.edu/stations/hort.htm>

Regan, R.P. 1991. Crop water requirements of container-grown plants. Comb. Proc. Int. Plant Prop. Soc. 41:229-231.

Sammis, T.W., C.L. Mapel, D.G. Lugg, R.R. Lansford, and J.T. McGuckin. 1985. Evapotranspiration crop coefficients predicted using growing-degree days. Trans. ASAE 28:773-780.

Ruter, J.M. 1998. Fertilizer rate and potin-pot production increases growth of 'Heritage' river birch. J. Environ. Hort. 16:135-138.

Schuch, U.K. and D.W. Burger. 1997. Water use and crop coefficients of woody ornamentals in containers. J. Amer. Soc. Hort. Sci. 122:727-734.

Young, R.E. and G.R. Bachman. 1996. Temperature distribution in large, pot-inpot nursery containers. J. Environ. Hort. 14:170-176.

Yrissarry, J.J.B. and F.S. Naveso. 2000. Use of weighing lysimeter and BowenRatio energy-balance for reference and actual crop evapotranspiration measurements. Acta Hort. 537:143-150. 